\title{
NEGOCJACJE W PRZEDSIĘBORSTWIE Z PERSPEKTYWY ZARZĄDZANIA PROJEKTAMI
}

\begin{abstract}
Współczesne negocjacje gospodarcze cechuje znaczna złożoność i zmienność, które są powodowane przez wpływ globalnego, turbulentnego otoczenia przedsiębiorstw. Występują liczne i skomplikowane relacje o dwojakim charakterze: wewnątrz- i międzyorganizacyjnym. Często w negocjacjach rozważa się różnorodne zagadnienia, uczestniczy w nich wiele stron, mających zróżnicowane cele i interesy, zarówno wspólne, jak i przeciwstawne. Konieczne jest analizowanie wielu wariantów rozwiązań. Powstają obiektywne trudności doboru efektywnych strategii i technik negocjacyjnych. Wzrastają ryzyko, a nawet niepewność działania. Zawiera się krótkotrwałe, wirtualne kontrakty. Niezbędne jest zatem tworzenie i stosowanie koncepcji metodycznych opisu i analizy negocjacji, umożliwiających ich efektywną realizację w aktualnych warunkach. Celem artykułu jest prezentacja tego rodzaju koncepcji, opracowanej przez autora poprzez wykorzystanie podstawowych pojęć i idei zarządzania projektami. Podejście takie stanowi nowy punkt widzenia na negocjacje w firmie, odmienny od tradycyjnego ich ujęcia, tzn. traktowania ich jako specyficznego procesu. Najpierw zaprezentowano ogólne definicje rozważanych negocjacji, a także wskazano specyficzne cechy negocjacji jako projektu. Następnie omówiono kluczowe aspekty zarządzania projektami odniesione do negocjacji. Wreszcie wymieniono najważniejsze problemy do rozwiązania $\mathrm{w}$ ramach tych aspektów. Podsumowanie zawiera syntezę proponowanej koncepcji i kierunki dalszych badań.

Słowa kluczowe: negocjacje w przedsiębiorstwie, negocjacje jako projekt, aspekty zarządzania negocjacjami jako projektami, problemy zarządzania negocjacjami jako projektami
\end{abstract}

\section{NEGOCJACJE W FIRMIE JAKO PROJEKT}

Celem potraktowania negocjacji w firmie jako projektu należy najpierw wyjaśnić znaczenie dwóch kluczowych w tym wypadku terminów: negocjacji i projektu.

Jeśli chodzi o ogólny sposób rozumienia pojęcia negocjacji, to w literaturze przedmiotu najczęściej spotyka się różne ich interpretacje, tzn. traktuje się je jako²:

1. proces decyzyjny;

2. metodę kierowania konfliktem i osiągania porozumienia;

3. wzajemną zależność partnerów;

4. proces: komunikowania się, wymiany i tworzenia wartości.

W rozważanym obszarze najistotniejsza jest pierwsza z wymienionych interpretacji, natomiast pozostałe mają znaczenie uzupełniające. Negocjacje rozumiane jako interakcyjny proces podejmowania decyzji w jego fazie przygotowawczej strony realizują niezależ-

\footnotetext{
${ }^{1}$ Dr hab. Andrzej Kozina, Katedra Procesu Zarządzania, Wydział Zarządzania, Uniwersytet Ekonomiczny w Krakowie, ul. Rakowicka 27, 31-510 Kraków, tel. 12293 74 76, e-mail: kozinaa@uek.krakow.pl

2 Wymienione interpretacje negocjacji omówiono w literaturze przedmiotu, m.in. w opracowaniach: R.J. Lewicki, D.M. Saunders, B. Barry, Essentials of Negotiation, wyd. 5, McGraw-Hill Publishing Co., New York 2010, s. 4 i n.; R. Rzadca, Negocjacje w interesach, PWE, Warszawa 2003, s. 23 i n.; A. Kozina, Planowanie negocjacji $w$ przedsiębiorstwie, Wydawnictwo Uniwersytetu Ekonomicznego w Krakowie, Kraków 2012, s. 21-24.
} 
nie od siebie (z punktu widzenia ich celów). Następnie dokonują wzajemnych uzgodnień w zakresie dwóch par zbiorów: alternatyw rozwiązań i kryteriów oceny, określonych wstępnie dla każdej ze stron z osobna w efekcie analizy problemu decyzyjnego. Wreszcie strony wybierają kryteria z punktu widzenia ich interesów i ustalają zbiór alternatyw (jako część wspólną wyjściowych opcji).

Negocjacje w przedsiębiorstwie obejmują wszelkie ich rodzaje wynikające z jego istoty jako szczególnego rodzaju organizacji. Stanowią one instrument zarządzania firmą. Bierze się tutaj pod uwagę zarówno te sytuacje, w których firma stanowi środowisko negocjacji, jak i te, dla których jest ich stroną. Rozważane negocjacje mogą więc być prowadzone pomiędzy wewnętrznymi grupami interesów, na przykład pracodawcami i pracobiorcami, właścicielami i menedżerami, konkurującymi i zarazem współdziałającymi oddziałami itp., jak i pomiędzy reprezentantami firmy z interesariuszami zewnętrznymi, na przykład dostawcami, odbiorcami, kooperantami itp. Negocjacje stanowią więc sposób kształtowania relacji firmy z otoczeniem i wewnętrznych warunków współdziałania ${ }^{3}$.

Dla każdej sytuacji negocjacyjnej w firmie ich zleceniodawcą jest odpowiedni kierownik, nadzorujący daną dziedzinę działalności (projekt, proces itp.), która determinuje rodzaj, przedmiot i zakres negocjacji lub delegowany przezeń pracownik wykonawczy (odpowiedzialni także za ich prowadzenie). Może on pochodzić zarówno z danego zespołu funkcjonalnego lub projektowego (najczęściej w negocjacjach wewnątrzorganizacyjnych), jak i zespołu negocjacyjnego (zadaniowego), reprezentującego firmę (zwykle w negocjacjach międzyorganizacyjnych).

Z kolei drugie z kluczowych pojęć rozważanych w niniejszej części artykułu, tzn. termin ,projekt” (z łac. proiectio - wyciągnięcie, wysunięcie ku przodowi), jest najogólniej rozumiane jako „,pomysł, zamiar, plan zamierzonej budowy, konstrukcji; model, szkic”4; zamierzony plan lub zamysł działania.

Z punktu widzenia miejsca i roli w firmie projekt jest traktowany jako rodzaj planu jednorazowego „o węższym zakresie i mniejszej złożoności niż program” (przypominający program, może być częścią szerszego programu, może to być jednak również samodzielny plan jednokrotnego użytku $)^{5}$. W innych interpretacjach podkreśla się ponadto, że projekt w odróżnieniu od programu ma mniejszą złożoność, jednorazowy cel, krótszy horyzont czasu, wymaga mniejszej ilości zasobów itp. ${ }^{6}$.

$\mathrm{Na}$ gruncie zarządzania projektami rozważane pojęcie jest na przykład interpretowane przez Adama Stabryłę jako ,przedstawienie opisu rozwiązania jakiegoś zadania (problemu), które w przyszłości ma zostać wykonane" ". Ponadto Stabryła proponuje określać pojęcie projektu w dwóch znaczeniach ${ }^{8}$ :

\footnotetext{
${ }^{3}$ Szerzej na temat pojęcia, rodzajów i znaczenia negocjacji w firmie traktuje opracowanie A. Kozina, op. cit., s. (odpowiednio) 21-24, 61-66 i 46-48.

${ }^{4}$ W. Kopaliński, Stownik wyrazów obcych i zwrotów obcojęzycznych, Wiedza Powszechna, Warszawa 1990, s. 415.

${ }^{5}$ R.W. Griffin, Podstawy zarządzania organizacjami, wyd. 2, PWN, Warszawa 2013, s. 227.

${ }^{6}$ Zob. np. R.L. Daft, Management, wyd. 10, South-Western Cengage Learning, Mason 2011, s. 221, oraz J.A. Pearce, R.B. Robinson, Management, McGraw-Hill Publishing Co., New York 1989, s. 248.

${ }^{7}$ A. Stabryła, Zarzadzanie projektami ekonomicznymi i organizacyjnymi, Wydawnictwo Naukowe PWN, Warszawa-Kraków 2006, s. 29.

${ }^{8}$ Ibidem, s. 30-31.
} 
1. Szerokim - projekt jest: modelem będącym usprawnieniem (modernizacją) określonego obiektu lub systemu lub rozwiązaniem bazowym (innowacją), stanowiącym wytwór o nowatorskiej formie i konstrukcji, który umożliwia realizację zamierzonego przedsięwzięcia jako zadania inwestycyjnego, operacyjnego, publicznego itp. (przedsięwzięcie kompleksowe), którego częściami są: opracowania studialne, modele (projekty modelowe), dokumentacja rozwiązań użytkowych (aplikacyjnych), efekty rzeczowe, na przykład inwestycji i działalności operacyjnej, w tym wszelkie zastosowane rozwiązania organizacyjne, techniczne, ergonomiczne i inne.

2. Wąskim - projekt może być rozumiany jako praca analityczno-badawcza, koncepcja budowy i funkcjonowania jakiegoś systemu, dokumentacja techniczna, program czy plan działania. W tym znaczeniu projekt nie obejmuje efektów rzeczowych.

Inne definicje eksponują różne aspekty projektu, nawiązujące do wymiarów zarządzania projektami (omówionych poniżej), takich jak jego cechy charakterystyczne, zasoby niezbędne do jego realizacji, proces opracowania, efekty wynikowe (wytwory i dokumentacja), czy wreszcie kwestie organizacji zespołu projektowego i zachowań jego członków ${ }^{9}$.

Nawet przedstawione określenia wskazują, że negocjacje w przedsiębiorstwie mogą być potraktowane jako specyficznego rodzaju projekty. Aby pełniej (precyzyjniej) scharakteryzować negocjacje w takim właśnie ujęciu, warto usystematyzować ich zasadnicze cechy na podstawie analizy porównawczej najczęściej wymienianych charakterystyk projektu, pojawiających się w jego różnych definicjach (różnie nazywanych, ale podobnie interpretowanych przez wielu autorów) ${ }^{10}$.

Można powiedzieć, że negocjacje jako projekt mają następujące cechy.

1. Są zorientowane na precyzyjnie i jednoznacznie zdefiniowany cel, wynikający przede wszystkim ze specyficznych potrzeb dziedziny działalności firmy, w której są stosowane jako instrument zarządzania, a konkretnie danego zadania (projektu, procesu itp.), oraz związany (w szerszym kontekście) ze strategią (planu ramowego, programu itp.) działania firmy.

2. Ich zakres (przedmiotowy) jest ograniczony, to znaczy stanowią zamkniętą całość, wyodrębnioną z innych zamierzeń, co wynika z ich specyfiki. Nie mogą bowiem dotyczyć nieokreślonych kwestii, lecz muszą się koncentrować na zagadnieniach, na których temat ich strony zgodziły się rozmawiać.

3. Mają charakter jednorazowy (niepowtarzalny, jednokrotny), unikatowy, wręcz nowatorski, zwłaszcza w wypadku negocjacji wyjątkowych, illub o znaczeniu strategicznym, na przykład w zakresie wdrażania innowacji czy dotyczących fuzji dwóch firm. Projekty mogą być również niepowtarzalne nie w znaczeniu dosłownym, lecz stanowiąc niepowtarzalne całości składające się z powtarzalnych

\footnotetext{
${ }^{9}$ Por. przykładowo: J.D. Frame, Zarzadzanie projektami w organizacjach, WIG-Press, Warszawa 2001, s. 2; H. Kerzner, Project Management. A Systems Approach to Planning, Scheduling, and Controlling, wyd. 11, John Wiley \& Sons Inc., New York 2013, s. 6; R.K. Wysocki, Efektywne zarzadzanie projektami. Tradycyjne, zwinne, ekstremalne, wyd. 6, Onepress, Warszawa 2013, s. 47-48, oraz J. Kisielnicki, Zarzq̨dzanie projektami. Ludzie - procedury - wyniki, Wolters Kluwer Polska, Warszawa 2011, s. 13-14.

${ }^{10}$ Szerzej wymienione cechy omówiono m.in. w opracowaniach: M. Trocki, B. Grucza, K. Ogonek, Zarzadzanie projektami, PWE, Warszawa 2003, s. 17-18 oraz R.K. Wysocki, op. cit., s. 48 i n.
} 
elementów. Z przypadkiem takim mamy do czynienia w szczególności podczas realizacji rutynowych transakcji, na przykład handlowych (zakupu lub sprzedaży) z wykorzystaniem trwale obowiązujących procedur i instrukcji formalizujących niektóre działania i metody w ramach tego rodzaju transakcji, między innymi zakres możliwych ustępstw, sposób analizy wiarygodności partnera czy oceny ryzyka.

4. Stanowią złożone, kompleksowe przedsięwzięcia, obejmujące wiele zadań, działań, etapów, faz itp. lub projektów cząstkowych, na przykład pojedynczych negocjacji w ramach długoterminowej umowy $\mathrm{z}$ danym kontrahentem - ma tutaj zastosowanie powszechnie stosowane ujęcie negocjacji gospodarczych jako procesu.

5. Sa ograniczone terminem realizacji, to znaczy mają limitowany czas trwania oraz precyzyjnie zdefiniowany początek i koniec. Podobnie jak w wypadku ich zakresu przedmiotowego ramy czasowe negocjacji stanowią przedmiot wstępnych uzgodnień ich stron przed rozpoczęciem rozmów, a ewentualne korekty dotyczące terminów i czasu ich trwania wymagają zwykle dodatkowych uzasadnień i ustaleń.

6. Są obarczone dużym stopniem trudności i ryzyka. Stopień ten zależy oczywiście od konkretnego rodzaju negocjacji. Generalnie są trudne, a często wręcz niemożliwe do ścisłego zaprogramowania. Ich ujęcia modelowe, najczęściej w postaci procesu, mają zatem relatywny charakter. Ryzyko w negocjacjach może mieć charakter pośredni, to znaczy wynikać ze specyfiki danej transakcji, oraz bezpośredni, czyli być generowane poprzez założenia i działania ich stron, a także ich uwarunkowania.

7. Realizacja negocjacji wymaga: planowania, nadzorowania i kontrolowania działań ludzi i zasobów, organizowania i koordynacji powiązanych ze sobą zadań oraz współpracy specjalistów z różnych dziedzin, posiadających kompetencje adekwatne do specyfiki danych negocjacji. Pod tym względem negocjacje nie różnią się od innych typowych działań i projektów realizowanych w przedsiębiorstwie.

8. W efekcie realizacji negocjacji powstają unikatowe wyroby, usługi, koncepcje. Jak już wspomniano, negocjacje stanowią także proces tworzenia nowych wartości, zarówno materialnych (na przykład majątek o znacznej wartości jako efekt negocjacji dotyczących fuzji), jak i niematerialnych (nowe pomysły, idee, koncepcje), których bez prowadzenia negocjacji nie dałoby się uzyskać.

\section{ASPEKTY ZARZĄDZANIA NEGOCJACJAMI JAKO PROJEKTAMI}

Do opisu i analizy negocjacji w firmie najczęściej stosuje się podejście procesowe, które jest jednakże niewystarczające, gdyż nie uwzględnia wszystkich specyficznych cech tego rodzaju negocjacji oraz ich kontekstu organizacyjnego. Niezbędne jest zatem poszukiwanie nowych schematów metodycznych badania rozważanych negocjacji. Obiecujące efekty dało zastosowanie podejścia systemowego do stworzenia ogólnego modelu negocjacji w przedsiębiorstwie oraz teorii agencji jako narzędzia ich identyfikacji. Wydaje się, że dogodną płaszczyzną charakterystyki i analizy negocjacji w firmie jest zarządzanie projektami. Wynika to z tego, że negocjacje mogą być interpretowane jako specyficznego rodzaju projekty, co wcześniej już wykazano. 
W najszerszym ujęciu zarządzanie projektami można potraktować jako wyodrębnioną dziedzinę teorii i praktyki zarządzania, co uzasadnia nie tylko szeroki zakres rozważanego pojęcia, ale głównie znaczący dorobek naukowo-badawczy i aplikacyjny. Dla dalszych rozważań za najbardziej przydatną uznano następującą, szeroką i zarazem odpowiednio skonkretyzowaną interpretację zarządzania projektami, zaproponowaną przez Marka Pawlaka. Według niego zarządzanie projektami to „wypełnianie klasycznych funkcji zarządzania (planowanie, organizowanie, decydowanie, motywowanie) w odniesieniu do specyficznych przedsięwzięć, jakimi są projekty. Specyfika ta wynika przede wszystkim z faktu, że są to przedsięwzięcia nietypowe, skomplikowane, angażujące różnych specjalistów”11. Pawlak rozróżnia cztery następujące wymiary (aspekty) zarządzania projekta$\mathrm{mi}^{12}$.

1. funkcjonalny - co należy zrobić (jakie są funkcje), mieszczą się tutaj następujące aspekty cząstkowe: prace przygotowawcze, czyli planowanie projektu, sterowanie nim i kontrola realizacji, ustalanie i przekazywanie idei i wyników;

2. instytucjonalny - struktury organizacyjne zarządzania projektami i ich umiejscowienie w strukturze przedsiębiorstwa oraz aspekty personalne, w tym: wybór odpowiedniego modelu organizacyjnego, organizacyjne włączenie grupy projektowej do struktury zarządzania i określenie instancji decyzyjnych;

3. instrumentalny (narzędziowy) - sposoby realizacji prac, w szczególności techniki planowania i kontrolowania, rozwiązywania problemów, projektowania systemów, formułowania celów, oceny i decydowania;

4. kierowanie grupą projektowa - powołanie odpowiedniej osoby do pełnienia funkcji kierownika projektu, utworzenie zespołu projektowego, organizowanie współpracy, procesu komunikowania się, motywowania, rozwiązywania konfliktów, postępowania $\mathrm{z}$ oporem przed zmianami. Rozważany aspekt można dla uproszczenia nazwać „,decyzyjnym”.

Inne interpretacje zarządzania projektami eksponują jeden, kilka, niekiedy wszystkie spośród wymienionych aspektów, na przykład Harold Kerzner akcentuje aspekt funkcjonalny ${ }^{13}$, Dennis Lock podkreśla aspekt instrumentalny ${ }^{14}$, a William R. Duncan uwzględnia oba te aspekty i zwraca uwagę na rolę interesariuszy projektu, co ma związek $\mathrm{z}$ aspektem instytucjonalnym ${ }^{15}$.

Niektóre definicje można natomiast potraktować jako poszerzenie interpretacji Pawlaka, gdyż eksponują dodatkowe aspekty zarządzania projektami. Na przykład w jednej z definicji mówi się o zaspokojeniu wymagań (co do efektów projektu) nie tylko interesariuszy, ale także w zakresie zakresu, czasu, kosztów, ryzyka i jakości projektu, czyli o aspekcie efektywnościowym ${ }^{16}$. Z kolei Celia Burton i Norma Michael, traktując zarządzanie projektami jako: „proces, w ramach którego menedżer projektu planuje zadania w obrębie projektu, steruje nimi, dysponuje zasobami udostępnionymi przez organizację dla realizacji przedsięwzięcia”, eksponują także aspekt przedmiotowy (rolę zasobów) ${ }^{17}$.

\footnotetext{
${ }^{11}$ M.L. Pawlak, Zarzadzanie projektami, Wydawnictwo Naukowe PWN, Warszawa 2006, s. 28.

${ }^{12}$ Ibidem, s. 28.

${ }^{13}$ H. Kerzner, op. cit., s. 4.

${ }^{14}$ D. Lock, Project Management, wyd. 10, Gower, Aldershot 2013, s. 1.

${ }^{15}$ A Guide to the Project Management Body of Knowledge, wyd. 4, Project Management Institute, Newtown Square, PA. 2009, s. 6.

${ }^{16}$ Ibidem, s. 6-7.

${ }^{17}$ C. Burton, N. Michael, Zarzadzanie projektem. Jak to robić w twojej organizacji, Astrum, Wrocław 1999, s. 20.
} 
Wydaje się, że wymienione aspekty należy uzupełnić jeszcze jednym, a mianowicie celowościowym, który obejmuje wymagania wobec negocjacji jako projektu i zarazem instrumentu zarządzania oraz ich zakres.

Biorąc pod uwagę wyodrębnione aspekty oraz nadając im logiczną kolejność, to znaczy porządkując je ze względu na ich istotę i znaczenie, można przedstawić ich charakterystykę w odniesieniu do negocjacji w przedsiębiorstwie.

1. Aspekt celowościowy - ogólne cele negocjacji (jako instrumentu zarządzania) są zdeterminowane przez potrzeby (wymagania) określonego zadania (projektu, przedsięwzięcia, transakcji itp.), do którego realizacji są one wykorzystywane jako narzędzie. Są także pochodną ogólnych zamierzeń firmy, wynikających z jej strategii. Stanowią więc cele „zewnętrzne”, formułowane przez nadzorujących negocjacje (cele cząstkowe i pośrednie determinują inne wymiary). Ogólne problemy negocjacji - podobnie jak ich cele - są uwarunkowane specyfiką obszarów działalności przedsiębiorstwa, w ramach których występują. Szczegółowe zagadnienia są zdeterminowane poprzez poszczególne rodzaje negocjacji realizowane $\mathrm{w}$ firmie, opisywane przez parametry sytuacji negocjacyjnej (strony, problemy, uwarunkowania itp.) oraz charakterystyki kontekstu organizacyjnego.

2. Aspekt funkcjonalny - ogólny proces negocjacji (metaproces), obejmujący trzy następujące podprocesy (procesy cząstkowe) ${ }^{18}$ :

1) planowanie - zapewnienie warunków do prowadzenia negocjacji;

2) prowadzenie - dochodzenie do porozumienia poprzez rozwiązywanie problemów, kształtowanie relacji, ustępstwa i uzgodnienia, rozwiązywanie konfliktów itp.;

3) podsumowanie - formułowanie i zawieranie umowy oraz ocena przebiegu negocjacji,

przy czym każda z wymienionych faz składa się z wielu etapów, a w ich ramach obejmuje wiele poszczególnych działań.

3. Aspekt instytucjonalny - najogólniej mówiąc, stanowią zasoby ludzkie - stanowiska i komórki organizacyjne działające $\mathrm{w}$ ramach rozwiązania strukturalnego firmy oraz realizujące funkcje w procesie negocjacji (lub reprezentujące firmę), o określonym zakresie kompetencji formalnych i potencjale wiedzy, zdolności i umiejętności, w tym: stanowiska kierownicze - odpowiedzialne za nadzorowanie procesów negocjacji - i wykonawcze - zajmujące się ich prowadzeniem. Zalicza się tutaj więc zarówno zespoły negocjacyjne (reprezentantów firmy) bezpośrednio realizujące zadania dotyczące negocjacji, jak i pracowników sztabowych odpowiedzialnych za wykonywanie działań o charakterze pomocniczym.

4. Aspekt decyzyjny - menedżerowie liniowi i funkcjonalni nadzorujący (formalnie) i wspomagający (merytorycznie) wszelkie procesy negocjacyjne w firmie (w przydzielonych im obszarach decyzyjnych) oraz szefowie zespołów negocjacyjnych (jako zespołów zadaniowych lub wirtualnych), przydzielający zadania ich członkom, kontrolujący ich pracę oraz sterujący danym procesem negocjacji. Konkretne zadania kierownicze różnią się w zależności od szczebla w hierarchii rozkazodawczej oraz rangi negocjacji.

\footnotetext{
${ }^{18}$ A. Kozina, op. cit., s. 69-72.
} 
Negocjacje w przedsiębiorstwie...

5. Aspekt przedmiotowy - zasoby rzeczowe tworzone illub wykorzystywane w negocjacjach, w tym zasoby: informacyjne (bazy danych i wiedzy); finansowe (wydatki na realizację całego procesu); techniczne (sprzęt i oprogramowanie, sieci i nośniki danych) oraz rzeczowe (fizyczne - inne wyposażenie, materiały, czas i przestrzeń).

6. Aspekt instrumentalny - różnorodne, szczegółowe narzędzia (instrumenty), czyli modele, zasady, metody, techniki, kryteria itp., stosowane do realizacji poszczególnych działań w procesie negocjacji, to znaczy rozwiązywania pojawiających się w nich problemów. W szczególności mieszczą się tutaj cztery podstawowe grupy metod i modeli: analiza decyzji, teoria gier, behawioralna teoria decyzji $\mathrm{i}$ analiza negocjacji ${ }^{19}$, a także wiele narzędzi pomocniczych, adaptowanych $\mathrm{z}$ innych obszarów zarządzania, na przykład techniki analizy strategicznej czy metody heurystyczne.

7. Aspekt efektywnościowy - cele negocjacji wyrażane poprzez syntetyczne kryteria efektywności konkretnych przedsięwzięć, na przykład opłacalności czy zyskowności transakcji z punktu widzenia interesów firmy. Z kolei realizacja procesów negocjacyjnych wymaga ponoszenia różnego rodzaju nakładów, w tym kosztów bezpośrednich i pośrednich oraz osobowych i rzeczowych. Wstępne porównanie i analiza przewidywanych efektów i kosztów negocjacji są dokonywane w fazie ich planowania (ex ante), natomiast końcowa ocena ich efektywności $\mathrm{w}$ fazie ich podsumowania (ex post).

Reasumując, można powiedzieć, że scharakteryzowane wymiary pozwalają na stworzenie pełnej i wszechstronnej charakterystyki negocjacji w firmie, wystarczającej do opisu i analizy ich różnych rodzajów.

\section{PROBLEMY ZARZĄDZANIA NEGOCJACJAMI JAKO PROJEKTAMI}

Interpretacja negocjacji w firmie jako projektu i ich charakterystyka z perspektywy zarządzania projektami umożliwiają nie tylko dokładne scharakteryzowanie tych negocjacji, stwarzają także możliwość identyfikacji najważniejszych problemów wymagających rozwiązania w celu stosowania przedstawionej koncepcji metodycznej do analizy i rozwiązywania praktycznych problemów negocjacyjnych. Problemy te można zestawić w przekroju wyróżnionych wcześniej aspektów zarządzania projektami.

1. Aspekt celowościowy - zasadniczym problemem jest zapewnienie zgodności celów poszczególnych negocjacji pomiędzy sobą, biorąc pod uwagę ich wzajemne powiązania w czasie i przestrzeni (synergiczne i konfliktowe) oraz z ogólnymi celami firmy - użytecznym narzędziem jest w tym wypadku powszechnie znana technika zarządzania przez cele, która sama w sobie zawiera specyficzne negocjacje, pozwalające na dokonywanie niezbędnych uzgodnień w celu zapewnienia wspomnianej zgodności celów.

2. Aspekt funkcjonalny - jak wspomniano, koncepcje opisu negocjacji jako procesu są powszechnie stosowane. Ciągle jednak niedostatecznie rozpoznanym zagadnieniem jest kwestia strukturalizacji jednej $\mathrm{z}$ istotnych grup działan $\mathrm{w}$ ramach ostatniej fazy tego procesu, to znaczy oceny efektywności negocjacji. Negocjacje

\footnotetext{
${ }^{19}$ H. Raiffa, J. Richardson, D. Metcalfe, Negotiation Analysis. The Science And Art of Collaborative Decision Making, The Belknap Press of Harvard University Press, Cambridge 2002, s. XI.
} 
zasadnicze (działania przy stole negocjacyjnym) - jak wiadomo - praktycznie nie poddają się strukturalizacji. Można natomiast i należy poszukiwać cząstkowych modeli opisu niektórych działań w ramach rozważanego podprocesu negocjacji, na przykład argumentowania czy zadawania pytań oraz procesów decyzyjnych, ale w ograniczonym zakresie, czyli w formie quasi-algorytmów dla typowych sytuacji decyzyjnych. Podobnie można opisywać niektóre techniki negocjacyjne. Stosunkowo najlepiej ugruntowany poznawczo jest podproces planowania negocjacji w firmie.

3. Aspekt instytucjonalny - najważniejszym zagadnieniem jest tutaj odpowiedni stopień formułowania, zlecania i formalizacji zadań i działań dla realizatorów procesów negocjacyjnych. Zagadnienie to nabiera szczególnego znaczenia w ramach nowoczesnych, elastycznych i „płynnych” struktur organizacyjnych - procesowych, sieciowych i wirtualnych, utrudniających zwłaszcza formalizację działań w zakresie negocjacji.

4. Aspekt decyzyjny - analogicznie jak wyżej, ale w odniesieniu do działań kierowniczych. Występuje tutaj klasyczny problem podziału i delegowania uprawnień decyzyjnych, którego rozwiązywanie dla poszczególnych przypadków negocjacyjnych jest utrudnione ze względu na ich różnorodność i zmienność. Wymagane jest zatem stosowanie podejścia sytuacyjnego.

5. Aspekt przedmiotowy - istotne jest wykorzystywanie wypracowanych w innych obszarach zarządzania oraz tworzenie nowych zasad alokacji i oceny produktywności zasobów. Ten aspekt zarządzania negocjacjami jako projektem wydaje się najmniej potrzebny i zarazem najmniej obiecujący, zarówno z poznawczego, jak i aplikacyjnego punktu widzenia.

6. Aspekt instrumentalny - ten aspekt jest natomiast bardzo obiecujący i zarazem ważny, a więc wymagający poszukiwania nowych rozwiązań. Chodzi o poszerzanie zbioru pomocniczych narzędzi negocjacji poprzez tworzenie, weryfikowanie i stosowanie nowych modeli, metod i technik oraz adaptację tych, które są wykorzystywane w innych obszarach zarządzania, na przykład klasycznych narzędzi organizatorskich (wykres kompetencji, diagram procesu itp.), technik analizy strategicznej, np. powszechnie znanej metody SWOT, scenariuszy itp., czy metod twórczego myślenia, a zwłaszcza analizy morfologicznej.

7. Aspekt efektywnościowy - niewątpliwie najważniejszy i zarazem najtrudniejszy do opisu i analizy aspekt negocjacji w firmie. Podstawowym celem jest poszukiwanie narzędzi szacowania kosztów i efektów negocjacji oraz tworzenie kryteriów, wzorców i zasad oceny efektywności negocjacji.

Ze względu na charakter negocjacji wyszczególnione problemy wymagają rozwiązania niejako na dwóch poziomach: po pierwsze w wymiarze ogólnym, tj. teoretycznometodologicznym, jak i w odniesieniu do każdej typowej sytuacji negocjacyjnej w przedsiębiorstwie. Zestawienie owych problemów pozwala na wskazanie kierunków dalszych badań, zmierzających do uszczegółowienia koncepcji opisu i analizy negocjacji w firmie z perspektywy zarządzania projektem, co będzie przedmiotem kolejnych opracowań autora.

\section{PODSUMOWANIE}

Reasumując, wydaje się, że przedstawiona koncepcja metodyczna opisu i analizy negocjacji w przedsiębiorstwie z perspektywy zarządzania projektami (w swej obecnej po- 
staci) może stanowić użyteczny instrument realizacji tego typu negocjacji (ich różnych typów). Stanowi swoistą „skrzynkę narzędziową” przydatną do rozwiązywania praktycznych problemów negocjacyjnych, zarówno typowych (powtarzalnych), jak i bezprecedensowych, o znaczeniu strategicznym. Istotną zaletą tej koncepcji jest bowiem uniwersalność i wieloaspektowość podejścia. Jeśli chodzi o szczegółowe narzędzia prowadzenia negocjacji (w ramach proponowanej koncepcji), to zaleca się przede wszystkim stosowanie: zasad i metod analizy sytuacji negocjacyjnej oraz interesariuszy negocjacji, szacowania ryzyka i siły przetargowej stron, prawidłowego formułowania celów negocjacji oraz zadań negocjatorów, ustalania reguł decyzyjnych, alokacji i racjonalizacji wykorzystania zasobów, doboru strategii i technik negocjacyjnych, formalizacji działań w negocjacjach, a zwłaszcza tworzenia i doskonalenia procedur, ich prowadzenia oraz analizy ich efektywności jako projektu.

Z kolei jednak koncepcja ta wymaga udoskonalenia, zwłaszcza w zakresie opracowywania nowych metod szczegółowych, rozwiązywania wskazanych problemów lub adaptowania na potrzeby negocjacji narzędzi stosowanych nie tylko w zarządzaniu projektem, ale także w innych obszarach zarządzania, co będzie przedmiotem dalszych badań autora. Przewidywana jest także weryfikacja empiryczna proponowanej koncepcji w badaniach o charakterze porównawczym dotyczących wielu różnorodnych negocjacji w firmie traktowanych jako specyficzne projekty.

\section{LITERATURA}

[1] A Guide to the Project Management Body of Knowledge, wyd. 4, Project Management Institute, Newtown Square, PA. 2009.

[2] Burton C., Michael N., Zarzadzanie projektem. Jak to robić w twojej organizacji, Astrum, Wrocław 1999.

[3] Daft R.L., Management, wyd. 10, South-Western Cengage Learning, Mason 2011.

[4] Frame J.D., Zarzadzanie projektami w organizacjach, WIG-Press, Warszawa 2001.

[5] Griffin R.W., Podstawy zarzadzania organizacjami, wyd. 2, Wydawnictwo Naukowe PWN, Warszawa 2013.

[6] Kerzner H., Project Management. A Systems Approach to Planning, Scheduling, and Controlling, wyd. 11, John Wiley \& Sons Inc., New York 2013.

[7] Kisielnicki J., Zarzadzanie projektami. Ludzie - procedury - wyniki, Wolters Kluwer Polska, Warszawa 2011.

[8] Kopaliński W., Stownik wyrazów obcych i zwrotów obcojęzycznych, Wiedza Powszechna, Warszawa 1990.

[9] Kozina A., Planowanie negocjacji w przedsiębiorstwie, Wydawnictwo UEK, Kraków 2012.

[10] Lewicki R.J., Saunders D.M., Barry B., Essentials of Negotiation, wyd. 5, McGraw-Hill Publishing Co., New York 2010.

[11] Lock D., Project Management, wyd. 10, Gower, Aldershot 2013.

[12] Pawlak M.L, Zarzadzanie projektami, Wydawnictwo Naukowe PWN, Warszawa 2006.

[13] Pearce J.A., Robinson R.B., Management, McGraw-Hill Publishing Co., New York 1989.

[14] Raiffa H., Richardson J., Metcalfe D., Negotiation Analysis. The Science And Art of Collaborative Decision Making, The Belknap Press of Harvard University Press, Cambridge 2002.

[15] Rządca R., Negocjacje w interesach, PWE, Warszawa 2003.

[16] Stabryła A., Zarzadzanie projektami ekonomicznymi i organizacyjnymi, Wydawnictwo Naukowe PWN, Warszawa-Kraków 2006.

[17] Trocki M., Grucza B., Ogonek K., Zarzadzanie projektami, PWE, Warszawa 2003.

[18] Wysocki R.K., Efektywne zarzadzanie projektami. Tradycyjne, zwinne, ekstremalne, wyd. 6., Onepress, Warszawa 2013. 


\section{NEGOTIATIONS IN A COMPANY FROM THE PERSPECTIVE OF PROJECT MANAGEMENT}

Contemporary business negotiations are characterized by substantial complexity and changeability, caused by the impact of global, turbulent environment of companies. Numerous and complicated interactions of dual character occur: intra- and inter-organizational ones. Frequently in negotiations many various issues are being considered, many parties participate to them, having differential objectives and interests, either common or opposed ones. It is necessary to analyze many alternatives. Objective difficulties to select effective negotiation strategies and techniques arise. Risk or uncertainty of performance increases. Agreements of short duration, virtual ones are being made. Therefore it is indispensable to create and implement methodological concepts of negotiations description and analysis, enabling us to perform negotiations effectively under present circumstances.

The objective of the paper is to present such a concept, elaborated by the author by applying basic notions and ideas of project management. Such an approach constitutes a new point of view on negotiations in a company, distinct from their traditional framework, i.e. treating them as specific process. At first the general definitions of negotiations were presented as well as their features as a project were pointed out. Then the par oft the crucial aspects of project management related to negotiations were discussed. Finally, the most important problems to be solved in the frame of those aspects were enumerated. The closing part contains the synthesis of suggested concept and the areas of subsequent research.

Keywords: negotiations in a company, negotiations as a project, the aspects of managing negotiations as projects, the problems of managing negotiations as projects

\section{DOI: 10.7862/rz.2014.mmr.5}

Tekst złożono w redakcji: styczeń 2014

Przyjęto do druku: marzec 2014 